\title{
An Implication of Spectral Interference of Lanthanum on Different Analytes for Their Determination in Lanthanum Matrix by CCD Detector-based ICP-AES
}

\author{
Arijit Sengupta $^{a *}$, Nishesh Kumar Gupta ${ }^{b}$, and Yougant Airan ${ }^{c}$ \\ ${ }^{a}$ Radiochemistry Division, Bhabha Atomic Research Centre, Mumbai, India \\ b Chemistry Dept., National Institute of Technology, Rourkela, Odisha, India \\ ${ }^{\mathrm{c}}$ Chemistry Department, Hindu College, University of Delhi, Delhi, India
}

\section{INTRODUCTION}

Inductively coupled plasma atomic emission spectrometry (ICPAES) is one of the most widely used analytical techniques for trace metal characterization due to its simplicity and simultaneous multielement determination capability coupled with adequate sensitivity, analytical range, and good precision of the determinations (1-6). ICP-AES has demerit as well with regard to spectral interference from emission-rich matrix elements, especially rare earth elements, on the determination of analytes at trace levels (7-12). In addition, interferences in ICP-AES are of chemical origin and during nebulization and atomization. To minimize spectral interference, the emission-rich matrix element is preferentially separated from the trace analytes either physically using the d.c.arc carrier distillation techniques or chemically by selective extraction of the emission-rich matrix element from the nalytes using a suitable ligand system (1318). These techniques are time-consuming for sample preparation including dissolution of the solid samples, feed conditioning, separation, etc. The most challenging task is the selective separation of one rare earth element from others, especially for the determination of trace rare earth elements in other rare earth matrices.

Lanthanides are found in a number of minerals, but their separation into individual metals requires complex techniques and the whole

*Corresponding autbor.

:E-mail: arijita@barc.gov.in

\section{ABSTRACT}

Lanthanum is found in relatively large quantities in the Earth's crust (32 ppm). Thus, there is a greater chance of La to be present in living systems, geological samples, and minerals. The presence of La even at trace amounts can interfere in the determination of other analytes in the samples. The present work is a systematic study of spectral interference caused by La on different analytes (Ag, Al, Ba, B, Bi, $\mathrm{Ca}, \mathrm{Cd}, \mathrm{Co}, \mathrm{Nd}, \mathrm{Er}, \mathrm{Pr}, \mathrm{Lu}, \mathrm{Ce}$, $\mathrm{Dy}, \mathrm{Eu}, \mathrm{Sm}, \mathrm{Cr}, \mathrm{Cu}, \mathrm{Fe}, \mathrm{Ga}, \mathrm{Gd}$, $\mathrm{Mg}, \mathrm{Mn}, \mathrm{Na}, \mathrm{Ni}, \mathrm{Sr}, \mathrm{Zn}$, and $\mathrm{Pb}$ ) in order to establish the interference-free analytical lines for the analytes under investigation in a La matrix and using a highly sensitive capacitive coupled device (CCD) detector-based ICP-AES. A reliable method for trace level determination of these analytes without chemical separation is developed. The analytical performance (detection limit, sensitivity, etc.) and the correction factor were evaluated. The proposed method was validated by analyzing synthetic samples prepared for all of the analytes under study.

process is cumbersome. Lanthanum ([Xe] $5 \mathrm{~d}^{1} 6 \mathrm{~s}^{2}$ ) finds various industrial applications (19-23) and is used to make Mischmetal, a pyrophoric alloy. As lanthanum oxide is used in vacuum tubes, optical glasses,and telescope lenses. Compounds of lanthanum serve as catalysts in petroleum cracking and cerium-doped lanthanum halides are used as inorganic scintillators. For industrial application, high purity $\mathrm{La}$ is the foremost require- ment which leads to developing a sound methodology for the trace level determination of analytes in a La matrix.

The direct determination of analytes at trace levels in an emissionrich matrix without any separation requires a systematic study on the spectral interference of the emission-rich element on the analytes. Keeping this objective in view, the present study on the spectral interference of La on different analytes (Ag, Al, Ba, B, Bi, Ca, Cd, Co, Nd, $\mathrm{Er}, \mathrm{Pr}$, Lu, Ce, Dy, Eu, Sm, Cr, Cu, $\mathrm{Fe}, \mathrm{Ga}, \mathrm{Gd}, \mathrm{Mg}, \mathrm{Mn}, \mathrm{Na}, \mathrm{Ni}, \mathrm{Sr}, \mathrm{Zn}$, and $\mathrm{Pb}$ ) has been conducted which involves identification of acceptable interference-free analytical lines, the tolerance level of La on the different analytical lines of these elements, and evaluation of the correction factors for these lines. Also the analytical performance of these lines in a La matrix involving detection limit, precision, sensitivity, and linear dynamic range were studied systematically. Considering these mentioned factors, a method was developed for the direct determination of these analytes at trace level in a La matrix without any separation. The results obtained with the proposed method were validated by using synthetic samples.

\section{EXPERIMENTAL}

\section{Instrumentation and Operating Conditions}

The analysis was carried out using a Spectro-Arcos inductively coupled plasma atomic emission spectrometer (ICP-AES) (SpectroArcos, Germany), with argon plasma as the excitation source and 
a capacitive coupled device (CCD) as the detector system. The instrumental specifications and optimized operating conditions are summarized in Table I.

\section{Standard Solutions and Reagents}

The standard solutions for all of the elements were prepared using CertiPUR $^{\circledR}$ ICP standard reference material solution of individual elements (E-Merck, Darmstadt, Germany). Suprapur ${ }^{\circledR} \mathrm{HNO}_{3}$ (E-Merck, Darmstadt, Germany) and quartz double-distilled water were used for all experimental purposes. Multi-point standardizations were carried out using $0.5 \mathrm{M} \mathrm{HNO}_{3}$ as the lower standard and 0.05-1000 $\mathrm{mg} / \mathrm{L}$ of the corresponding elemental standard as the higher standard for each line after proper peak search, auto attenuation, etc. For the analysis of each sample, 10 replicate measurements were performed, while for the determination of detection limits and sensitivity, 25 replicate measurements were taken into consideration.

\section{Methods}

A series of La solutions (commercially available standard reference material elemental solution from EMerck, Darmstadt, Germany) of varying concentrations from 0.05 to $1000 \mathrm{mg} / \mathrm{L}$ were prepared. Evaluation of the correction factor, contribution due to La in every different channel of each analyte, tolerance level, along with the analytical performance (detection limit, sensitivity, linear dynamic range, and precision for each analyte) were studied. By exploiting the idea of dependence of correction factor on concentration of the interfering element (La), it is much easier to directly determine the interference in the presence of other analytes by ICP-AES. Further, the analytical performance for each identified line of La was evaluated.
The developed methodology for the direct determination of trace amounts of the analytes was validated using synthetic samples without chemical separation.

\section{RESULTS AND DISCUSSION}

\section{Determination of La by ICP-AES}

The correction factor which quantifies the contribution of La depends on the concentration of La. For evaluating the contribution of La to different analytes, precise estimation of the amount in the sample is needed. In this study, an ICP-AES-based method was developed for the simultaneous determination of La along with different analytes under investigation, including some rare earth elements. Three different lines of La, i.e.,

\section{Atomic Apectroscopy 1 Vol. 38(2), Mar./Apr. 2017}

$333.749 \mathrm{~nm}, 379.478 \mathrm{~nm}$, and $408.672 \mathrm{~nm}$ were chosen on the basis of the analytical performance. The calibration curves for these three lines were established and are illustrated in Figure 1.

The sensitivity of these analytical lines followed the trend: 408.672 $\mathrm{nm}>379.478 \mathrm{~nm}>333.749 \mathrm{~nm}$, while for the detection limits the reverse trend was observed: $333.749 \mathrm{~nm}>379.478 \mathrm{~nm}>$ $408.672 \mathrm{~nm}$. For the sensitivity of the analytical lines, the slope of the calibration curves was taken into account, whereas the detection limits were calculated as the concentration equivalent to the intensity of the blank $(\langle\mathrm{x}\rangle)+5$ times the relative standard deviation for the blank $(5 \sigma)$. Synthetic samples containing $\mathrm{La}$ in the concentration

TABLE I

Specifications and Instrumental Operating Conditions of ICP-AES Instrumental Specifications

\begin{tabular}{ll} 
Model No. & Arcos FH12 ICP-AES \\
Optical design & Paschen-Runge mounting, Circular design \\
Focal length & $750 \mathrm{~mm}$ \\
Grating & Holographic \\
Groove density & 1800 grooves/mm (1), 3600 grooves/mm (2) \\
Wavelength range & $130-800 \mathrm{~nm}$ \\
Entrance slit width & 15 microns \\
Resolution (FWHM) & $0.01 \mathrm{~nm}$ from $130-450 \mathrm{~nm}$ \\
& $0.02 \mathrm{~nm}$ from $450-800 \mathrm{~nm}$ \\
Thermal regulation & Controlled to $30 \pm 1{ }^{\circ} \mathrm{C}$ \\
Frequency & $27.12 \mathrm{MHz}$ \\
Pump & Dual channel peristaltic pump \\
Detector & Linear arrays of CCD (3648 pixels/array) \\
Nebulizer & Concentric nebulizer with cyclonic spray \\
ICP torch & chamber \\
\hline Operating Condition & Demountable, radial viewing \\
Coolant flow & $16 \mathrm{~L} / \mathrm{min}$ \\
Auxiliary flow & $0.7 \mathrm{~L} / \mathrm{min}$ \\
Total time of measurement & $30 \mathrm{~s}$ \\
Pump speed & $25 \mathrm{Rpm}$ \\
RF power output & $1.0 \mathrm{~kW}$ \\
Input power & $230 \mathrm{~V}$ AC \\
\hline
\end{tabular}


range of $0.05-1000 \mathrm{mg} / \mathrm{L}$ were analyzed using these analytical lines. The results obtained are tabulated in Table II revealing that the three lines of La can be used for the determination of La up to 1000 $\mathrm{mg} / \mathrm{L}$ with an acceptable (\%)RSD (relative standard deviation). Beyond this concentration, no experiment was conducted because of choking in the nebulizer system. Based on the above study, it is clear that the La $408.672-\mathrm{nm}$ line is the best line for its ICP-AES determination.

\section{Spectral Interference of La on Other Analytes}

Lanthanum, like other members of the lanthanide series, has emission line-rich spectra due to its multi-electronic nature and hence, may interfere in the analysis of other analytes most of which do not have emission-rich spectra and, therefore, have fewer lines for the analysis. On the basis of spectral interference and analytical performance (detection limit, sensitivity, linear dynamic range, and precision), the best line for each analyte was chosen. In the present study, all analytes under investigation with respect to the spectral interference of La are grouped separately.
Spectral Interference on Ag, B, $\mathrm{Ba}, \mathrm{Bi}, \mathrm{Ca}, \mathrm{Er}, \mathrm{Lu}, \mathrm{Fe}, \mathrm{Ga}, \mathrm{Mn}, \mathrm{Sr}$, and $\mathbf{P b}$

The spectral interference of $\mathrm{La}$ on $\mathrm{Ag}, \mathrm{B}, \mathrm{Ba}, \mathrm{Bi}, \mathrm{Ca}, \mathrm{Er}, \mathrm{Lu}, \mathrm{Fe}, \mathrm{Ga}$, $\mathrm{Mn}, \mathrm{Sr}$, and $\mathrm{Pb}$ was studied thoroughly using the different analytical lines of these analytes. For all of these analytical lines, the analytical performance was also evaluated in the presence of a La matrix (1000 mg/L). As depicted in Table III, the lines of $\mathrm{Ag} 328.068 \mathrm{~nm}$, B $208.959 \mathrm{~nm}, \mathrm{Ba} 455.404 \mathrm{~nm}$, Bi $306.772 \mathrm{~nm}$, Ca $315.887 \mathrm{~nm}$, Er $337.271 \mathrm{~nm}$, Lu $307.760 \mathrm{~nm}$, Fe 373.486 nm, Ga 417.206 nm, Mn $294.921 \mathrm{~nm}$, Sr $460.733 \mathrm{~nm}$, and $\mathrm{Pb} 405.778 \mathrm{~nm}$ were free of any spectral interference from $\mathrm{La}$ (1000 mg/L). Fortunately, all of these analytical lines showed better analytical performance, including sensitivity, detection limits, etc. (see Table IV). In view of this, all of the analytical lines mentioned above can be chosen for the trace level determination of these analytes in the presence of a La matrix. Among these analytes, the lines of Al $176.641 \mathrm{~nm}$, Bi $143.683 \mathrm{~nm}$, Er 326.478 nm,Dy 364.540 nm, and $\mathrm{Na} 330.298 \mathrm{~nm}$ (see Table III) showed significant spectral interference and were not used for the determination of these analytes in the presence of a La matrix.

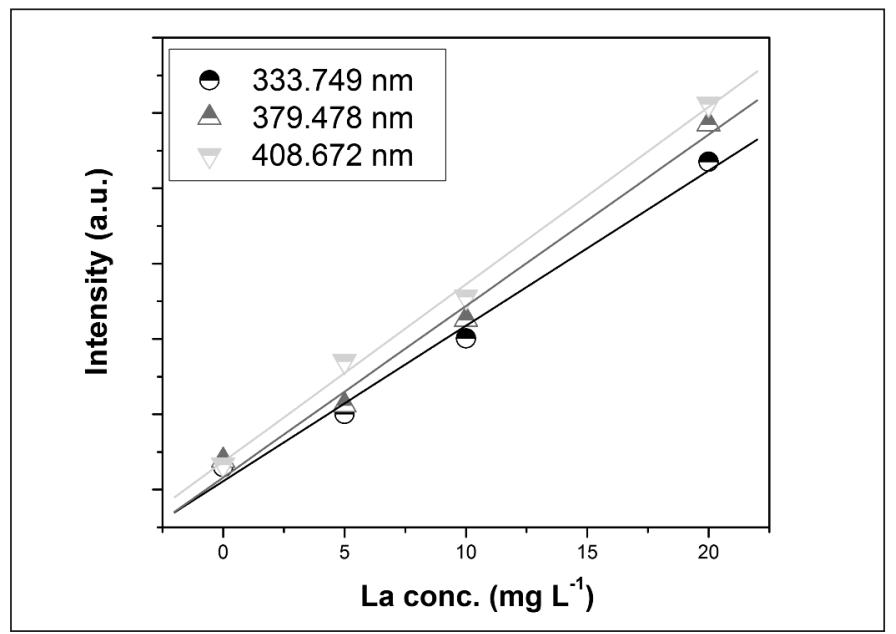

Fig. 1. Calibration curves for different analytical lines of La.
Spectral Interference on Al, Pr, $\mathrm{Cr}$, and $\mathrm{Ni}$

For these analytes, two of the analytical lines were interferencefree. The results of the spectral interference of $\mathrm{La}$ on $\mathrm{Al}, \mathrm{Pr}, \mathrm{Cr}$, and $\mathrm{Ni}$ are listed in Table V, while the analytical performance of the least interfered analytical lines of these elements are listed in Table VI.

\section{Aluminum (Al)}

For Al, six different analytical lines were chosen for this study (167.078 nm, $396.152 \mathrm{~nm}, 394.401$ $\mathrm{nm}, 176.641 \mathrm{~nm}, 308.215 \mathrm{~nm}$, and $309.271 \mathrm{~nm})$. Al $308.215 \mathrm{~nm}$ and Al $309.271 \mathrm{~nm}$ showed least interference for La matrix. By taking the analytical performance (detection limits, sensitivity, etc.) into consideration, $\mathrm{Al} 308.215 \mathrm{~nm}$ is believed to be the best line for further investigation. The Al $176.641 \mathrm{~nm}$ line interfered to maximum and should not be taken into consideration for trace level study.

\section{Praseodymium (Pr)}

For Pr, four different analytical lines were chosen for the spectral interference study $(411.846 \mathrm{~nm}$, $417.939 \mathrm{~nm}, 422.535 \mathrm{~nm}$, and $414.311 \mathrm{~nm}$ ). Two of the four lines of $\operatorname{Pr} 417.939 \mathrm{~nm}$ and $\operatorname{Pr} 422.535$ nm were free of any spectral interference of La. Pr $417.939 \mathrm{~nm}$ with a detection limit of $0.038 \mathrm{mg} / \mathrm{L}$ and a sensitivity of 3600 counts/mg/L appeared to be the best choice for

TABLE II Determination of La by ICP-AES

\begin{tabular}{llll}
\hline $\begin{array}{c}\text { Analytical Line } \\
(\mathrm{nm})\end{array}$ & 333.749 & 379.478 & 408.672 \\
\hline $\begin{array}{c}\text { Sensitivity } \\
\left(\text { counts } \mathrm{mg} \mathrm{L}^{-1}\right)\end{array}$ & 4120 & 4551 & 4709 \\
$\begin{array}{c}\text { Detection limit } \\
\left(\mathrm{mg} \mathrm{L}^{-1}\right)\end{array}$ & 0.036 & 0.033 & 0.01 \\
$\begin{array}{c}\text { Linear dynamic } \\
\text { range (mg L-1) }\end{array}$ & $0.036-1600$ & $0.033-1400$ & $0.01-2000$ \\
\begin{tabular}{l} 
RSD (\%) \\
\hline
\end{tabular} & 2 & 1.6 & 1.1 \\
\hline
\end{tabular}


TABLE III:

Spectral Interference of $\mathrm{La}$ on

$\mathrm{Ag}, \mathrm{B}, \mathrm{Ba}, \mathrm{Bi}, \mathrm{Ca}, \mathrm{Er}, \mathrm{Lu}, \mathrm{Fe}, \mathrm{Ga}, \mathrm{Mn}, \mathrm{Sr}$, and $\mathrm{Pb}$

\begin{tabular}{|c|c|c|c|c|c|}
\hline Elements & $\begin{array}{l}\text { Analytical } \\
\text { Lines (nm) }\end{array}$ & $\begin{array}{c}\text { Contribution } \\
(\mathrm{mg} / \mathrm{L})\end{array}$ & Elements & $\begin{array}{l}\text { Analytical } \\
\text { Lines (nm) }\end{array}$ & $\begin{array}{c}\text { Contribution } \\
(\mathrm{mg} / \mathrm{L})\end{array}$ \\
\hline \multirow[t]{4}{*}{ Ag } & 338.289 & 0.18 & Lu & 261.542 & 0.03 \\
\hline & 328.068 & $*$ & & 291.139 & 0.09 \\
\hline & 224.641 & 6.66 & & 307.760 & $*$ \\
\hline & 243.779 & 1.77 & & 219.554 & 0.23 \\
\hline \multirow[t]{5}{*}{ B } & 249.773 & 0.41 & $\mathrm{Fe}$ & 259.941 & 0.25 \\
\hline & 249.677 & 0.20 & & 238.204 & 0.42 \\
\hline & 182.641 & 0.38 & & 239.562 & 0.24 \\
\hline & 208.959 & $*$ & & 244.451 & 2.09 \\
\hline & 136.246 & 21.56 & & 261.187 & 0.37 \\
\hline \multirow[t]{3}{*}{$\mathrm{Ba}$} & 455.404 & $*$ & & 262.567 & 2.71 \\
\hline & 233.527 & 0.84 & & 262.829 & 1.32 \\
\hline & 230.424 & 0.43 & & 275.573 & 0.64 \\
\hline \multirow[t]{7}{*}{$\mathrm{Bi}$} & 223.061 & 9.89 & & 241.331 & 1.19 \\
\hline & 190.241 & 7.69 & & 373.486 & $*$ \\
\hline & 306.772 & $*$ & $\mathrm{Ga}$ & 141.444 & 80.00 \\
\hline & 222.825 & 7.71 & & 417.206 & $*$ \\
\hline & 153.317 & 50.00 & & 294.364 & 0.31 \\
\hline & 143.683 & 363.00 & & 287.424 & 6.77 \\
\hline & 206.170 & 3.86 & Mn & 257.611 & 0.04 \\
\hline \multirow[t]{6}{*}{$\mathrm{Ca}$} & 396.847 & 0.36 & & 259.373 & 0.04 \\
\hline & 393.366 & 0.39 & & 260.569 & 0.04 \\
\hline & 317.933 & 0.37 & & 294.921 & $*$ \\
\hline & 315.887 & $*$ & & 403.076 & 2.81 \\
\hline & 183.801 & 11.33 & $\mathrm{Sr}$ & 407.771 & 0.43 \\
\hline & 422.673 & 0.17 & & 421.552 & 0.02 \\
\hline \multirow[t]{8}{*}{$\mathrm{Er}$} & 337.271 & $*$ & & 460.733 & $*$ \\
\hline & 349.910 & 140.00 & $\mathrm{~Pb}$ & 220.353 & 0.89 \\
\hline & 326.478 & 560.00 & & 168.215 & 50.00 \\
\hline & 323.058 & 30.00 & & 167.153 & 60.00 \\
\hline & & & & 172.680 & 50.00 \\
\hline & & & & 405.778 & $*$ \\
\hline & & & & 283.305 & 0.31 \\
\hline & & & & 261.418 & 2.57 \\
\hline
\end{tabular}

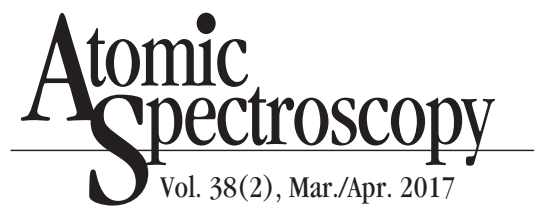

the trace level determination of $\operatorname{Pr}$ in La matrix.

\section{Chromium (Cr)}

The contribution of La for the four lines of $\mathrm{Cr}$ followed the trend: $283.563 \mathrm{~nm} \sim 284.325 \mathrm{~nm}<$ $205.618 \mathrm{~nm}<267.716 \mathrm{~nm}<$ $284.984 \mathrm{~nm}$. Cr $283.563 \mathrm{~nm}$ and $\mathrm{Cr}$ $284.325 \mathrm{~nm}$, with zero spectral interference at $1000 \mathrm{mg} / \mathrm{L}$ of $\mathrm{La}$, were further investigated for analytical performance. It was found that Cr $283.563 \mathrm{~nm}$ is the obvious selection for further analytical study.

\section{Nickel (Ni)}

In the case of $\mathrm{Ni}$, of the seven lines $(231.604 \mathrm{~nm}, 221.648 \mathrm{~nm}$, $232.003 \mathrm{~nm}, 227.021 \mathrm{~nm}, 174.828$ $\mathrm{nm}, 300.249 \mathrm{~nm}$, and $341.476 \mathrm{~nm}$ ) only Ni $300.249 \mathrm{~nm}$ and Ni 341.476 $\mathrm{nm}$ showed zero contribution value due to La. Ni $341.476 \mathrm{~nm}$ exceeded $\mathrm{Ni} 300.249 \mathrm{~nm}$ in analytical performance with a detection limit of $0.013 \mathrm{mg} / \mathrm{L}$ and sensitivity of 4200 counts $/ \mathrm{mg} / \mathrm{L}$ and is thus considered suitable for the trace level determination of $\mathrm{Ni}$ in a La matrix.

\section{Spectral Interference on Nd, Ce,} Dy, Eu, Sm, and Gd

Due to the line-rich emission spectra of rare earth elements (REEs), additional analytical lines are available, but complication increases due to higher chances of interference. Moreover, elements of this group have similar chemistry and because of this trace level determination of REEs in a rare earth matrix becomes difficult. The spectral interference results for these REEs are listed in Table VII and the analytical performance of the least interfered analytical lines is listed in Table VIII.

\section{Neodymium (Nd)}

Among the four analytical lines of $\mathrm{Nd}(401.225 \mathrm{~nm}, 430.358 \mathrm{~nm}$, $406.109 \mathrm{~nm}$, and $417.731 \mathrm{~nm}$ ), spectral interference from La up to $1000 \mathrm{mg} / \mathrm{L}$ was observed only for Nd $417.731 \mathrm{~nm}$. For detection lim- 
TABLE IV

Least Interfered Lines Ag, B, Ba, Bi, Ca, Er, Lu, Fe, Ga, Mn, Sr, and Pb and Their Analytical Performances In the Presence of La Matrix

\begin{tabular}{cccccc}
\hline \multirow{2}{*}{ Elements } & $\begin{array}{c}\text { Analytical } \\
\text { Lines }(\mathrm{nm})\end{array}$ & $\begin{array}{c}\text { Tolerance } \\
\text { Level }(\mathrm{mg} / \mathrm{L})\end{array}$ & $\begin{array}{c}\text { Correction } \\
\text { Factor }\end{array}$ & $\begin{array}{c}\text { Detection } \\
\text { Limits }(\mathrm{mg} / \mathrm{L})\end{array}$ & $\begin{array}{c}\text { Sensitivity } \\
\text { (counts/mg/L) }\end{array}$ \\
\hline $\mathrm{Ag}$ & 328.068 & 1000 & - & 0.010 & $1.37 \mathrm{E}+04$ \\
$\mathrm{~B}$ & 208.959 & 1000 & - & 0.010 & $4.31 \mathrm{E}+03$ \\
$\mathrm{Ba}$ & 455.404 & 1000 & - & 0.030 & $2.48 \mathrm{E}+03$ \\
$\mathrm{Bi}$ & 306.772 & 1000 & - & 0.340 & $1.52 \mathrm{E}+03$ \\
$\mathrm{Ca}$ & 315.887 & 1000 & - & 0.100 & $1.11 \mathrm{E}+03$ \\
$\mathrm{Lu}$ & 307.76 & 1000 & - & 0.095 & $2.86 \mathrm{E}+03$ \\
$\mathrm{Fe}$ & 373.486 & 1000 & - & 0.052 & $2.17 \mathrm{E}+03$ \\
$\mathrm{Ga}$ & 417.206 & 1000 & - & 0.033 & $7.69 \mathrm{E}+03$ \\
$\mathrm{Mn}$ & 294.921 & 1000 & - & 0.040 & $1.83 \mathrm{E}+03$ \\
$\mathrm{Sr}$ & 460.733 & 1000 & - & 0.033 & $2.31 \mathrm{E}+03$ \\
$\mathrm{~Pb}$ & 405.778 & 1000 & - & 0.127 & $7.77 \mathrm{E}+02$ \\
\hline
\end{tabular}

TABLE V

Spectral Interference of La on Al, Pr, Cr, and Ni

\begin{tabular}{cccccc}
\hline Elements & $\begin{array}{c}\text { Analytical } \\
\text { Lines }(\mathrm{nm})\end{array}$ & $\begin{array}{c}\text { Contribution } \\
(\mathrm{mg} / \mathrm{L})\end{array}$ & $\begin{array}{c}\text { Elements } \\
\text { Al }\end{array}$ & $\begin{array}{c}\text { Analytical } \\
\text { Lines }(\mathrm{nm})\end{array}$ & $\begin{array}{c}\text { Contribution } \\
(\mathrm{mg} / \mathrm{L})\end{array}$ \\
\hline & 167.078 & 73.00 & $\mathrm{Pr}$ & 411.846 & 0.61 \\
& 396.152 & 0.09 & & 417.939 & $*$ \\
& 394.401 & 6.36 & & 422.535 & $*$ \\
& 176.641 & 1400.00 & & 414.311 & 0.30 \\
& 308.215 & $*$ & $\mathrm{Ni}$ & 231.604 & 0.45 \\
$\mathrm{Cr}$ & 309.271 & $*$ & & 221.648 & 0.32 \\
& 267.716 & 0.30 & & 232.003 & 0.73 \\
& 205.618 & 0.07 & & 227.021 & 1.06 \\
& 283.563 & $*$ & 174.828 & 60.00 \\
& 284.325 & $*$ & 300.249 & $*$ \\
& 284.984 & 0.33 & 341.476 & $*$ \\
\hline
\end{tabular}

its, the trend followed the order: $401.225 \mathrm{~nm}<430.358 \mathrm{~nm}<$ $406.109 \mathrm{~nm}$, while for sensitivity it followed $430.358 \mathrm{~nm}<406.109 \mathrm{~nm}$ $<401.225 \mathrm{~nm}$. In accordance with the analytical performance, the $\mathrm{Nd}$ $401.225 \mathrm{~nm}$ line is considered to be the best line for Nd determination in a La matrix.

\section{Cerium (Ce)}

For Ce, the five analytical lines ( $418.660 \mathrm{~nm}, 448.691 \mathrm{~nm}, 413.765$ $\mathrm{nm}, 413.380 \mathrm{~nm}$, and $393.373 \mathrm{~nm}$ ) were interference-free from La. The detection limits for the analytical lines of Ce followed the order: $413.765 \mathrm{~nm}<413.382 \mathrm{~nm}<$ $418.660 \mathrm{~nm}<393.373 \mathrm{~nm}<$ $448.691 \mathrm{~nm}$. The trend followed on the basis of sensitivity was: 448.691 $\mathrm{nm}<418.660 \mathrm{~nm}<393.373 \mathrm{~nm}<$ $413.380 \sim 413.765 \mathrm{~nm}$. Considering the analytical performance, Ce $413.765 \mathrm{~nm}$ can be chosen for further study.

\section{Dysprosium (Dy)}

Of the five analytical lines for Dy chosen for the present purpose (353.170 nm, $394.468 \mathrm{~nm}, 340.780$ $\mathrm{nm}, 353.602 \mathrm{~nm}$, and $364.540 \mathrm{~nm}$ ), the three analytical lines of Dy $353.170 \mathrm{~nm}$, Dy $340.780 \mathrm{~nm}$, and Dy $353.602 \mathrm{~nm}$ showed least interference from La, while the Dy $364.540 \mathrm{~nm}$ line was most interfered from La. With regard to analytical performance, the Dy $353.170 \mathrm{~nm}$ and Dy $340.780 \mathrm{~nm}$ lines have the same detection limit value, but Dy $353.170 \mathrm{~nm}$ has maximum sensitivity and should be considered for further investigation.

\section{Europium (Eu)}

Of the four analytical lines of Eu ( $420.505 \mathrm{~nm}, 381.967 \mathrm{~nm}, 393.048$ $\mathrm{nm}$, and $390.710 \mathrm{~nm}$ ), only Eu $381.967 \mathrm{~nm}$ was slightly interfered by $\mathrm{La}$. The trend for the detection limit value for interference-free analytical lines of $\mathrm{Eu}$ is as follows: $420.505 \mathrm{~nm}<393.048 \mathrm{~nm}<$ $390.710 \mathrm{~nm}$. Sensitivity followed the order: $393.048 \mathrm{~nm}<390.710$ 
TABLE VI

Least Interfered Lines Of Al, Pr, Cr, and Ni and Their Analytical Performances In Presence Of La Matrix

\begin{tabular}{cccccc}
\hline Elements & Analytical & Tolerance & Correction & Detection & Sensitivity \\
& Lines $(\mathrm{nm})$ & Level $(\mathrm{mg} / \mathrm{L})$ & Factor & Limits $(\mathrm{mg} / \mathrm{L})$ & (counts/mg/L) \\
\hline $\mathrm{Al}$ & 308.215 & 1000 & - & 0.040 & $1.82 \mathrm{E}+03$ \\
$\mathrm{Al}$ & 309.271 & 1000 & - & 1.890 & $3.13 \mathrm{E}+03$ \\
$\mathrm{Pr}$ & 417.939 & 1000 & - & 0.038 & $3.60 \mathrm{E}+03$ \\
$\mathrm{Pr}$ & 422.535 & 1000 & - & 0.034 & $2.98 \mathrm{E}+03$ \\
$\mathrm{Cr}$ & 283.563 & 1000 & - & 0.010 & $3.60 \mathrm{E}+03$ \\
$\mathrm{Cr}$ & 284.325 & 1000 & - & 0.080 & $1.56 \mathrm{E}+03$ \\
$\mathrm{Ni}$ & 300.249 & 1000 & - & 0.111 & $6.42 \mathrm{E}+02$ \\
$\mathrm{Ni}$ & 341.476 & 1000 & - & 0.013 & $4.20 \mathrm{E}+03$ \\
\hline
\end{tabular}

TABLE VII

Spectral Interference of $\mathrm{La}$ on $\mathrm{Nd}, \mathrm{Ce}, \mathrm{Dy}, \mathrm{Eu}, \mathrm{Sm}$ and Gd

\begin{tabular}{|c|c|c|c|c|c|}
\hline Elements & $\begin{array}{l}\text { Analytical } \\
\text { Lines (nm) }\end{array}$ & $\begin{array}{c}\text { Contribution } \\
(\mathrm{mg} / \mathrm{L})\end{array}$ & Elements & $\begin{array}{l}\text { Analytical } \\
\text { Lines (nm) }\end{array}$ & $\begin{array}{c}\text { Contribution } \\
(\mathrm{mg} / \mathrm{L})\end{array}$ \\
\hline \multirow[t]{4}{*}{$\mathrm{Nd}$} & 401.225 & $*$ & $\mathrm{Eu}$ & 420.505 & $*$ \\
\hline & 430.358 & $*$ & & 381.967 & 0.03 \\
\hline & 406.109 & $*$ & & 393.048 & $*$ \\
\hline & 417.731 & 3.50 & & 390.710 & $*$ \\
\hline \multirow[t]{5}{*}{$\mathrm{Ce}$} & 418.660 & $*$ & Sm & 359.260 & $*$ \\
\hline & 448.691 & $*$ & & 442.434 & $*$ \\
\hline & 413.765 & $*$ & & 428.079 & $*$ \\
\hline & 413.380 & $*$ & & 360.428 & $*$ \\
\hline & 393.373 & $*$ & Gd & 342.247 & $*$ \\
\hline \multirow[t]{5}{*}{ Dy } & 353.170 & * & & 335.047 & $*$ \\
\hline & 394.468 & 1.01 & & 336.223 & $*$ \\
\hline & 340.780 & $*$ & & 335.862 & $*$ \\
\hline & 353.602 & $*$ & & & \\
\hline & 364.540 & 410.00 & & & \\
\hline
\end{tabular}

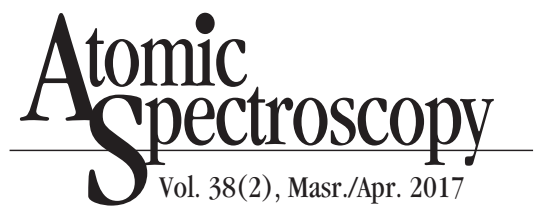

$\mathrm{nm}<420.505 \mathrm{~nm}$. Accordingly, Eu $420.505 \mathrm{~nm}$ is the best line for further analytical study of Eu in a La matrix.

\section{Samarium (Sm)}

For $\mathrm{Sm}$, the four analytical lines (359.260 nm, $442.434 \mathrm{~nm}, 428.079$ $\mathrm{nm}$, and $360.428 \mathrm{~nm}$ ) were free of any spectral interference by La up to $1000 \mathrm{mg} / \mathrm{L}$. Of the four, although Sm $428.079 \mathrm{~nm}$ and Sm 360.428 $\mathrm{nm}$ showed least detection limit values, the sensitivity for $\mathrm{Sm}$ $428.079 \mathrm{~nm}$ was higher and is considered the best line for trace level estimation of Sm in a La matrix.

\section{Gadolinium ( $G d)$}

The four analytical lines of $\mathrm{Gd}$ (342.247 nm, $335.047 \mathrm{~nm}, 336.223$ $\mathrm{nm}$, and $335.862 \mathrm{~nm}$ ) remain unaffected in the presence of a $\mathrm{La}$ matrix and showed no contribution, leaving the analytical performance as the only criterion for selecting the best line. Gd 335.047 $\mathrm{nm}$ with least detection limit and maximum sensitivity is the best line for trace level determination of $\mathrm{Gd}$ in a La matrix.

\section{Spectral Interference on Cd, Co, $\mathrm{Cu}, \mathrm{Mg}, \mathrm{Na}$, and $\mathrm{Zn}$}

The analytical lines of $\mathrm{Cd}, \mathrm{Co}$, $\mathrm{Cu}, \mathrm{Mg}, \mathrm{Na}$, and $\mathrm{Zn}$ were interfered by the La matrix at $1000 \mathrm{mg} / \mathrm{L}$. The best line for trace level determination of all of tese analytes in a $\mathrm{La}$ matrix was based on analytical performances. Table IX shows analytical performance of $\mathrm{Cd}, \mathrm{Co}, \mathrm{Cu}, \mathrm{Mg}$, $\mathrm{Na}$, and $\mathrm{Zn}$ in the presence of $\mathrm{La}$ at $1000 \mathrm{mg} / \mathrm{L}$. The analytical performance of the least interfered lines for all of these analytes are listed in Table X.

\section{Cadmium (Cd)}

The spectral interference of La on the four analytical lines of $\mathrm{Cd}$ followed the trend: $226.502 \mathrm{~nm}<$ $214.438 \mathrm{~nm}<228.802 \mathrm{~nm}<$ $361.051 \mathrm{~nm}$. The analytical performance (detection limit and sensitivity) for the Cd $226.502 \mathrm{~nm}$ was 
TABLE VIII

Least Interfered Lines of Nd, Ce, Dy, Eu, Sm and Gd and Their Analytical Performance in Presence of La Matrix

\begin{tabular}{|c|c|c|c|c|c|}
\hline Elements & $\begin{array}{l}\text { Analytical } \\
\text { Lines (nm) }\end{array}$ & $\begin{array}{l}\text { Tolerance } \\
\text { Level (mg/L) }\end{array}$ & $\begin{array}{l}\text { Correction } \\
\text { Factor }\end{array}$ & $\begin{array}{c}\text { Detection } \\
\text { Limits (mg/L) }\end{array}$ & $\begin{array}{c}\text { Sensitivity } \\
\text { (counts/mg/L) }\end{array}$ \\
\hline $\mathrm{Nd}$ & 401.225 & 1000 & - & 0.004 & $2.96 \mathrm{E}+03$ \\
\hline $\mathrm{Nd}$ & 430.358 & 1000 & - & 0.034 & $1.98 \mathrm{E}+03$ \\
\hline $\mathrm{Nd}$ & 406.109 & 1000 & - & 0.057 & $2.95 \mathrm{E}+03$ \\
\hline $\mathrm{Ce}$ & 418.66 & 1000 & - & 0.090 & $1.90 \mathrm{E}+03$ \\
\hline $\mathrm{Ce}$ & 448.691 & 1000 & - & 0.850 & $5.88 \mathrm{E}+01$ \\
\hline $\mathrm{Ce}$ & 413.765 & 1000 & - & 0.060 & $2.31 \mathrm{E}+03$ \\
\hline $\mathrm{Ce}$ & 413.38 & 1000 & - & 0.080 & $2.31 \mathrm{E}+03$ \\
\hline $\mathrm{Ce}$ & 393.373 & 1000 & - & 0.210 & $2.22 \mathrm{E}+03$ \\
\hline Dy & 353.17 & 1000 & - & 0.020 & $1.41 \mathrm{E}+04$ \\
\hline Dy & 340.78 & 1000 & - & 0.020 & $4.30 \mathrm{E}+03$ \\
\hline Dy & 353.602 & 1000 & - & 0.050 & $4.04 \mathrm{E}+03$ \\
\hline $\mathrm{Eu}$ & 420.505 & 1000 & - & 0.006 & $1.74 \mathrm{E}+04$ \\
\hline $\mathrm{Eu}$ & 393.048 & 1000 & - & 0.010 & $2.13 \mathrm{E}+03$ \\
\hline $\mathrm{Eu}$ & 390.71 & 1000 & - & 0.050 & $3.19 \mathrm{E}+03$ \\
\hline Sm & 359.26 & 1000 & - & 0.040 & $3.34 \mathrm{E}+03$ \\
\hline $\mathrm{Sm}$ & 442.434 & 1000 & - & 0.050 & $1.13 \mathrm{E}+03$ \\
\hline $\mathrm{Sm}$ & 428.079 & 1000 & - & 0.010 & $6.24 \mathrm{E}+03$ \\
\hline $\mathrm{Sm}$ & 360.428 & 1000 & - & 0.010 & $2.46 \mathrm{E}+02$ \\
\hline Gd & 342.247 & 1000 & - & 0.014 & $5.07 \mathrm{E}+03$ \\
\hline Gd & 335.047 & 1000 & - & 0.007 & $6.47 \mathrm{E}+03$ \\
\hline Gd & 336.223 & 1000 & - & 0.027 & $4.42 \mathrm{E}+03$ \\
\hline Gd & 335.862 & 1000 & - & 0.015 & $3.73 \mathrm{E}+03$ \\
\hline
\end{tabular}

TABLE IX

Spectral Interference of La on $\mathrm{Cd}, \mathrm{Co}, \mathrm{Cu}, \mathrm{Mg}, \mathrm{Na}$, and $\mathrm{Zn}$

\begin{tabular}{cccccc}
\hline Elements & $\begin{array}{c}\text { Analytical } \\
\text { Lines }(\mathrm{nm})\end{array}$ & $\begin{array}{c}\text { Contribution } \\
(\mathrm{mg} / \mathrm{L})\end{array}$ & $\begin{array}{r}\text { Elements } \\
\text { Lines }(\mathrm{nm})\end{array}$ & $\begin{array}{c}\text { Analytical } \\
\text { Ld }\end{array}$ & $\begin{array}{c}\text { Contribution } \\
\mathrm{Cd} / \mathrm{L})\end{array}$ \\
& 214.438 & 0.06 & $\mathrm{Co}$ & 228.616 & 0.40 \\
& 226.502 & 0.02 & & 238.892 & 0.43 \\
& 228.802 & 0.15 & & 230.786 & 1.58 \\
$\mathrm{Cu}$ & 361.051 & 4.04 & & 237.862 & 0.27 \\
& 324.754 & 0.04 & $\mathrm{Na}$ & 589.592 & 0.09 \\
& 327.396 & 0.03 & & 588.995 & 0.08 \\
& 224.700 & 0.19 & & 330.237 & 24.00 \\
& 219.226 & 0.89 & & 330.298 & 2250.00 \\
$\mathrm{Zn}$ & 219.958 & 0.44 & $\mathrm{Mg}$ & 279.553 & 0.07 \\
& 213.856 & 0.07 & & 280.270 & 0.08 \\
& 206.200 & 1.28 & & 285.213 & 0.06 \\
& 202.613 & 0.25 & & 279.079 & 0.64 \\
& 334.502 & 25.00 & & 202.647 & 0.64 \\
\hline
\end{tabular}

found to be superior over the other lines and hence, was chosen as the best line for the determination of $\mathrm{Cd}$ in the presence of La.

\section{Copper (Cu)}

For $\mathrm{Cu}$, five analytical lines (324.754 nm, $327.396 \mathrm{~nm}, 224.700$ $\mathrm{nm}, 219.226 \mathrm{~nm}$, and $219.958 \mathrm{~nm}$ ) were taken into consideration. The $\mathrm{Cu} 324.754 \mathrm{~nm}$ and $\mathrm{Cu} 327.396 \mathrm{~nm}$ lines showed least interference. The $\mathrm{Cu} 327.396 \mathrm{~nm}$ line with a detection limit of $0.003 \mathrm{mg} / \mathrm{L}$ and sensitivity of $3.40 \mathrm{E}+04$ counts/ $\mathrm{mg} / \mathrm{L}$ is considered the best line for trace level $\mathrm{Cu}$ determination with a tolerance level of $750 \mathrm{mg} / \mathrm{L}$.

\section{Zinc (Zn)}

The spectral interference study of La on the $\mathrm{Zn} 213.856 \mathrm{~nm}, \mathrm{Zn}$ $206.200 \mathrm{~nm}, \mathrm{Zn} 202.613 \mathrm{~nm}$, and $\mathrm{Zn} 334.502 \mathrm{~nm}$ lines revealed that the $\mathrm{Zn} 213.856 \mathrm{~nm}$ line was least interfered by La with a tolerance level of $500 \mathrm{mg} / \mathrm{L}$. The same line also showed the detection limit of $0.023 \mathrm{mg} / \mathrm{L}$ in a La matrix. Based on these factors, the $\mathrm{Zn} 213.856 \mathrm{~nm}$ line should be the best choice for further investigation.

\section{Cobalt (Co)}

The spectral interference of a La matrix on the Co determination followed the trend: $237.862 \mathrm{~nm}<$ $228.616 \mathrm{~nm}<238.892 \mathrm{~nm}<$ $230.786 \mathrm{~nm}$. The Co $237.862 \mathrm{~nm}$ line with a detection limit of 0.05 $\mathrm{mg} / \mathrm{L}$ and sensitivity of 826 counts/ $\mathrm{mg} / \mathrm{L}$ is the best choice for the trace level determination of Co in a La matrix in $100 \mathrm{mg} / \mathrm{L}$ tolerance level.

\section{Sodium (Na)}

In case of $\mathrm{Na}$, the $330.298 \mathrm{~nm}$ line had severe spectral interference from La and should not be considered for study. Of the four analytical lines of $\mathrm{Na}(589.592 \mathrm{~nm}$, $588.995 \mathrm{~nm}, 330.237 \mathrm{~nm}$, and $330.298 \mathrm{~nm}$ ), the $588.995 \mathrm{~nm}$ line with a $400 \mathrm{mg} / \mathrm{L}$ La tolerance level was chosen for further investiga- 
TABLE $\mathbf{X}$

Least Interfered Lines of $\mathrm{Cd}, \mathrm{Co}, \mathrm{Cu}, \mathrm{Mg}, \mathrm{Na}$, and $\mathrm{Zn}$ and Their Analytical Performance in Presence of La Matrix

\begin{tabular}{lccccc}
\hline Elements & $\begin{array}{c}\text { Analytical } \\
\text { Lines }(\mathrm{nm})\end{array}$ & $\begin{array}{c}\text { Tolerance } \\
\text { Level }(\mathrm{mg} / \mathrm{L})\end{array}$ & $\begin{array}{c}\text { Correction } \\
\text { Factor }\end{array}$ & $\begin{array}{c}\text { Detection } \\
\text { Limits }(\mathrm{mg} / \mathrm{L})\end{array}$ & $\begin{array}{c}\text { Sensitivity } \\
(\text { counts/mg/L) }\end{array}$ \\
\hline $\mathrm{Cd}$ & 226.502 & 800 & $2 \mathrm{E}-6$ & 0.003 & $1.15 \mathrm{E}+04$ \\
$\mathrm{Co}$ & 228.616 & 100 & $4 \mathrm{E}-4$ & 0.050 & $8.26 \mathrm{E}+02$ \\
$\mathrm{Cu}$ & 327.396 & 750 & $3 \mathrm{E}-6$ & 0.003 & $3.40 \mathrm{E}+04$ \\
$\mathrm{Mg}$ & 285.213 & 500 & $6.00 \mathrm{E}-05$ & 0.005 & $1.55 \mathrm{E}+04$ \\
$\mathrm{Na}$ & 588.995 & 400 & $8.00 \mathrm{E}-05$ & 0.016 & $5.34 \mathrm{E}+04$ \\
$\mathrm{Zn}$ & 213.856 & 500 & $7.00 \mathrm{E}-05$ & 0.023 & $4.57 \mathrm{E}+03$ \\
\hline
\end{tabular}

TABLE XI

Validation of Method Using Synthetic Samples Containing Ag, Al, Ba, B, Bi, Ca, Nd, Er, Pr, Lu, Ce, Dy, Eu, Sm, Cr, Fe, Ga, Gd, Mn, Ni, Sr, and $\mathrm{Pb}$ in Lanthanum Matrix

\begin{tabular}{lccllc}
\hline Elements & $\begin{array}{c}\text { Amountl } \\
\text { Added } \\
(\mathrm{mg} / \mathrm{L})\end{array}$ & $\begin{array}{c}\text { Amount } \\
\text { Estimated } \\
(\mathrm{mg} / \mathrm{L})\end{array}$ & $\begin{array}{c}\text { Elements } \\
\text { Amount } \\
\text { Added } \\
(\mathrm{mg} / \mathrm{L})\end{array}$ & $\begin{array}{c}\text { Amount } \\
\text { Estimated } \\
(\mathrm{mg} / \mathrm{L})\end{array}$ \\
\hline $\mathrm{Ag}$ & 0.05 & $0.048 \pm 0.003$ & $\mathrm{Eu}$ & 0.05 & $0.050 \pm 0.004$ \\
$\mathrm{Al}$ & 0.05 & $0.047 \pm 0.004$ & $\mathrm{Sm}$ & 0.05 & $0.049 \pm 0.003$ \\
$\mathrm{~B}$ & 0.05 & $0.050 \pm 0.006$ & $\mathrm{Cr}$ & 0.05 & $0.050 \pm 0.001$ \\
$\mathrm{Ba}$ & 0.05 & $0.048 \pm 0.002$ & $\mathrm{Er}$ & 0.05 & $0.052 \pm 0.002$ \\
$\mathrm{Bi}$ & 0.05 & $0.051 \pm 0.003$ & $\mathrm{Fe}$ & 0.05 & $0.048 \pm 0.003$ \\
$\mathrm{Ca}$ & 0.05 & $0.052 \pm 0.002$ & $\mathrm{Ga}$ & 0.05 & $0.049 \pm 0.004$ \\
$\mathrm{Nd}$ & 0.05 & $0.049 \pm 0.003$ & $\mathrm{Gd}$ & 0.05 & $0.051 \pm 0.005$ \\
$\mathrm{Pr}$ & 0.05 & $0.051 \pm 0.003$ & $\mathrm{Mn}$ & 0.05 & $0.049 \pm 0.003$ \\
$\mathrm{Lu}$ & 0.05 & $0.049 \pm 0.001$ & $\mathrm{Ni}$ & 0.05 & $0.048 \pm 0.001$ \\
$\mathrm{Ce}$ & 0.05 & $0.048 \pm 0.006$ & $\mathrm{Sr}$ & 0.05 & $0.050 \pm 0.002$ \\
$\mathrm{Dy}$ & 0.05 & $0.049 \pm 0.002$ & $\mathrm{~Pb}$ & 0.05 & $0.052 \pm 0.003$ \\
\hline
\end{tabular}

TABLE XII

Validation of Method Using Synthetic Samples Containing $\mathrm{Cd}, \mathrm{Co}, \mathrm{Cu}, \mathrm{Mg}, \mathrm{Na}$, and $\mathrm{Zn}$ in Lanthanum Matrix

\begin{tabular}{cccc}
\hline Element & $\begin{array}{c}\text { Amount } \\
\text { Added } \\
(\mathrm{mg} / \mathrm{L})\end{array}$ & $\begin{array}{c}\text { Amount } \\
\text { Estimated } \\
(\mathrm{mg} / \mathrm{L})\end{array}$ & $\begin{array}{c}\text { Amount Estmated After } \\
\text { Incorporating } \\
\text { Correction Factor } \\
(\mathrm{mg} / \mathrm{L})\end{array}$ \\
\hline $\mathrm{Cd}$ & 0.1 & 0.13 & 0.11 \\
$\mathrm{Co}$ & 0.1 & 0.51 & 0.11 \\
$\mathrm{Cu}$ & 0.1 & 0.12 & 0.09 \\
$\mathrm{Mg}$ & 0.1 & 0.15 & 0.09 \\
$\mathrm{Na}$ & 0.1 & 0.18 & 0.1 \\
$\mathrm{Zn}$ & 0.1 & 0.16 & 0.09 \\
\hline
\end{tabular}

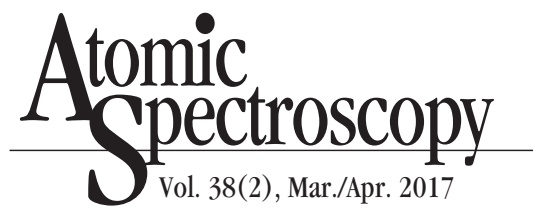

tion. The detection limit of the $\mathrm{Na}$ $588.995 \mathrm{~nm}$ line was $0.016 \mathrm{mg} / \mathrm{L}$ with a sensitivity of $5.34 \mathrm{E}+04$ counts/mg/L

\section{Magnesium (Mg)}

The five analytical lines of $\mathrm{Mg}$ showed some interference in a $\mathrm{La}$ matrix. The trend followed 285.213 $\mathrm{nm}<279.553 \mathrm{~nm}<280.270 \mathrm{~nm}<$ $279.079 \mathrm{~nm} \sim 202.647 \mathrm{~nm}$. For the trace level determination of $\mathrm{Mg}$ in a La matrix, the $\mathrm{Mg} 285.213 \mathrm{~nm}$ line (detection limit of $0.005 \mathrm{mg} / \mathrm{L}$, sensitivity of $1.55 \mathrm{E}+04)$ is the best option with a $500 \mathrm{mg} / \mathrm{L}$ tolerance level of La.

\section{Validation of Method Using Synthetic Samples Containing Analytes in a La Matrix}

The main aim of the present study was to develop a simple methodology for the direct determination of the analytes in the presence of a La matrix without any need for chemical separation. Based on the above studies, the most suitable analytical lines of the analytes were identified. A set of synthetic samples was prepared using commercially available standard reference materials of the individual element solutions followed by feeding of the samples into the plasma directly without chemical separation and the results were analyzed. The following synthetic samples were prepared to validate the proposed method:

(a). $0.05 \mathrm{mg} / \mathrm{L}$ of $\mathrm{Ag}, \mathrm{Al}, \mathrm{Ba}, \mathrm{B}$, $\mathrm{Bi}, \mathrm{Ca}, \mathrm{Nd}, \mathrm{Er}, \mathrm{Pr}, \mathrm{Lu}, \mathrm{Ce}, \mathrm{Dy}, \mathrm{Eu}$, $\mathrm{Sm}, \mathrm{Cr}, \mathrm{Fe}, \mathrm{Ga}, \mathrm{Gd}, \mathrm{Mn}, \mathrm{Ni}, \mathrm{Sr}$, and $\mathrm{Pb}$ in $1000 \mathrm{mg} / \mathrm{L}$ of $\mathrm{La}$.

(b). $0.1 \mathrm{mg} / \mathrm{L}$ of $\mathrm{Cd}, \mathrm{Co}, \mathrm{Cu}, \mathrm{Mg}$, $\mathrm{Na}$ and $\mathrm{Zn}$ in $1000 \mathrm{mg} / \mathrm{L}$ of La.

The amount added to the synthetic samples and that estimated by application of the ICP-AES-based proposed method was in close agreement after incorporating the correction factor for some of the analytical lines of the analytes. Tables XI and XII show the results 
obtained for all of the analytes under investigation. Thus, the developed method was validated for the direct determination of the analytes at trace level in the presence of a La matrix without using any chemical separation.

\section{CONCLUSION}

The detailed and systematic studies on the spectral interference by La on different analytes and the analytical performance of the different analytical lines of these analytes revealed that the following lines: Ag 328.068 nm, Al 308.215 nm, B $208.959 \mathrm{~nm}, \mathrm{Ba} 455.404 \mathrm{~nm}$, Bi $306.772 \mathrm{~nm}$, Ca $315.887 \mathrm{~nm}$, $\mathrm{Nd} 401.225 \mathrm{~nm}$, Er $337.271 \mathrm{~nm}$, Pr $417.939 \mathrm{~nm}$, Lu $307.760 \mathrm{~nm}$, Ce 413.765 nm, Dy $353.170 \mathrm{~nm}$, Eu 420.505 nm, Sm 428.079 nm, Cr $283.563 \mathrm{~nm}$, Fe $373.486 \mathrm{~nm}$, Ga 471.206 nm, Gd 335.047 nm, Mn $294.921 \mathrm{~nm}$, Ni $341.476 \mathrm{~nm}$, $\mathrm{Sr} 460.733 \mathrm{~nm}$, and $\mathrm{Pb} 405.778 \mathrm{~nm}$ were not interfered by the La matrix and also showed the best analytical performance. These lines can be chosen for the determination of these analytes in the presence of a La matrix without chemical separation. Integrated with the correction factor, Cd $226.502 \mathrm{~nm}$, Co $228.616 \mathrm{~nm}, \mathrm{Cu}$ $327.396 \mathrm{~nm}, \mathrm{Mg} 285.213 \mathrm{~nm}, \mathrm{Na}$ $588.995 \mathrm{~nm}$, and $\mathrm{Zn} 213.856 \mathrm{~nm}$ are the analytical lines that can serve the purpose of trace level determination for $\mathrm{Cd}, \mathrm{Co}, \mathrm{Cu}, \mathrm{Mg}$, $\mathrm{Na}$, and $\mathrm{Zn}$, respectively, in a $\mathrm{La}$ matrix.

A simple, rapid ICP-AES-based method was developed for the determination of these analytes in a La matrix without chemical separation. The method was validated using synthetic samples prepared from reference materials.

Received May 23, 2016.

\section{REFERENCES}

1. A. Sengupta, V. C. Adya and S. V. Godbole, Spectral interference study of uranium on other analytes by using CCD based ICP-AES, J.Radioanal.Nucl. Chem. DOI 10.1007/s10967-013-2520-0 (2013).

2. A. Sengupta, B. Rajeswari, R.M. Kadam, and S.V. Godbole, At. Spectrosc. 33(2), 48 (2012).

3. A.Sengupta, M. J. Kulkarni and S. V. Godbole, J. Radioanal. Nucl. Chem. 289 (3), 961 (2011).

4. A. Sengupta, B. Rajeswari, R.M. Kadam, and R. Acharya, At Spectrosc. 32(5), 200 (2011).

5. P. W. J. M. Bowmans, Fresenius Z. Anal. Chem., 299, 337 (1979).

6. R. M. Barnes, CRC Crit. Rev. Anal. Chem. 7, 203 (1978).

7. Y.Airan, A.Sengupta, S.K. Thulasidas, and V. Natarajan, At. Spectrosc., 36 (5), 221, (2015).

8. A. Sengupta, Y. Airan, S.K. Thulasidas and V. Natarajan, At. Spectrosc. $37(2), 50$ (2016).

9. A.Sengupta, Y.Airan, S.K. Thulasidas and V. Natarajan, At. Spectrosc. 37(2), 61 (2016).

10. Y. Airan, A. Sengupta, S.K. Thulasidas and V.Natarajan, At. Spectrosc. 36(1), 30 (2015).

11. A.Sengupta, Y. Airan, S.K. Thulasidas, and V.Natarajan, At. Spectrosc. 36(2), 82 (2015).

12. J. P.Robin, Pro. Anal. At. Spectrosc. 5, 79 (1982).

13. A.A. Argekar, M.J. Kulkarni, J.N Mathur and A.G. Page, Talanta 56(4), 591 (2002).

14. V. Krivan, R. Hausbeck, P. Wilhartitz, R. Krismer and H. M. Ortner, Fresenius' Anal. Chem. 341(9), 550 (1991).

15. P. Liang, Y. Liu and L.Guo, J. Anal. At. Spectrom. 19, 1006 (2004).

16. R.K. Malhotra and K. Satyanarayana, Talanta 50(3), 601 (1999)

17. R. Wanjau, H. Bin, J. Zucheng, Q. Yongchao, H. Man, L. Pei, J. Rare Earths 22(2), 197 (2004).

18. N. Pathak,V.C. Adya, S.K. Thulasi- das, A. Sengupta, T.K. Seshagiri, and S.V. Godbole, At. Spectrosc. 35(1), 17 (2004).

19. R. Talebi, M. Nasiri and S. Rahnamaeiyan, J. Mater. Sci: Mater. Electronics 27(2), 1500 (2016).

20. Y. Kawabe, A. Yamanaka, E. Hanamura, T. Kimura, Y. Takiguchi, H. Kan and Y. Tokura, J. Appl. Phys. 88, 1175 (2000).

21. M. M. Boucek and R. Snyderman, Science 193 (4256), 905 (1976).

22. S. P. Simnerz, J. F. Bonnett, N. L. Canfield, K. D. Meinhardt, V. L. Sprenkle and J. W. Stevenson, Electrochem. Solid-State Lett. 5 (7), A173 (2002).

23. W. Hea, S. Schuetzb, R. Solankia, J. Belotb and J. McAndrew, Electrochem. Solid-State Lett. 7 (7), G131 (2004).

24. H. Wang, J. J. Wang, G. Roy, M.Jean-SébastienLehnc, H.Lic, D.Hongc and D. V. Shenaic, Electrochem. Solid-State Lett. 12 (4), G13 (2009)

25. J. W. Yanz, Z. G. Lu, Y. Jiang, Y. L. Dong, C. Y. Yu and W. Z. Li, J. Electrochem. Soc. 149 (9), A1132 (2002). 